\title{
EFFECT OF PATELLAR RESURFACING ON CLINICAL OUTCOMES, RANGE OF KNEE MOTION AND ANTERIOR KNEE PAIN IN PATIENTS WITH TOTAL KNEE ARTHROPLASTY
}

Ozgur Korkmaz, Yıldıray Genc, Osman Cimen, Ismail Oltulu, Deniz Gülabi and Gultekin Cecen

Medicalpark Pendik Hospital Istanbul, Turkey

\author{
EFEKTI PATERLARNE REPOZICIJE NA KLINIČKE ISHODE, OPSEG \\ POKRETA KOLENA I BOLA U PREDNJEM DELU KOLENA \\ KOD PACIJENATA SA TOTALNOM ARTOPLASTIKOM KOLENA \\ Ozgur Korkmaz, Jildirej Genc, Osman Cimen, Ismail Oltulu, Deniz Gulabi i Gultekin Cecen \\ Medicinski park Pendik bolnica, Istanbul, Turska
}

\begin{abstract}
Objectives: In this study, we retrospectively compare the clinical results, range of knee motion and anterior knee pain in patients on whom we performed knee arthroplasty with and without patellar resurfacing.

Thirty-eight patients were evaluated in the study. Knee Society scores, knee range of motion and anterior knee pain before and 12 months after surgery were detected. Patients were divided into two groups: resurfaced patellas and nonresurfaced patellas. There were 18 patients in the resurfaced group and 20 patients in the nonresurfaced group.

Mean Knee Society score was $40.72 \pm 13.09$ in the resurfaced group and $38.55 \pm 5.88$ in the nonresurfaced group before surgery. Mean Knee Society score was $80.38 \pm 7.78$ in the resurfaced group and 80.10 \pm 3.22 in the nonresurfaced group in the last control. Mean knee range of motion was $92.83 \pm 12.12$ degrees in the resurfaced group and 91.05 \pm 10.10 degrees in the nonresurfaced group before surgery. Mean range of motion was 106.22 \pm 9.13 degrees in the resurfaced group and $97.25 \pm 8.50$ degrees in the nonresurfaced group after surgery. There were twelve patients with anterior pain before surgery in the resurfaced group and 13 patients with anterior knee pain before surgery in the nonresurfaced group. After surgery, there was one patient with anterior pain in the resurfaced group and 9 patients with anterior knee pain in the nonresurfaced group.

Anterior knee pain ratio was smaller in the resurfaced group than in the nonresurfaced group, and there was a significant difference in range of knee motion as a result of our study. We offered to resurface the patella.
\end{abstract}

Keywords: patella, motion of knee, surgical intervention

\section{SAŽETAK}

U ovoj retrospektivnoj studiji, uporedili smo kliničke karakteristike, stepen pokretljivosti zgloba kolena i prisustvo bola u prednjem delu kolena kod pacijenata kod kojih je uradjena artoplastika kolena sa ili bez repozicije patele.

Trideset osam pacijenata je uključeno u studiju. Knee Society skorovi, opseg pokreta u zglobu kolena i prisustvo bola su praćeni pre i 12 meseci posle hirurške intervencije. Pacijenti su bili podeljeni u dve grupe: grupa pacijenata sa repozicijom patele $i$ bez nje. U grupi sa repozicijom bilo je 18, a u grupi bez repozicije 20 pacijenata.

Srednja vrednost Knee Society skora u grupi sa repozi-

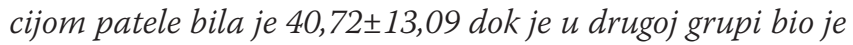
$38,55 \pm 5,88$ pre operacije. Posle operacije, u grupi ispitanika

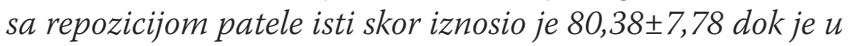

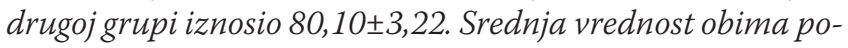

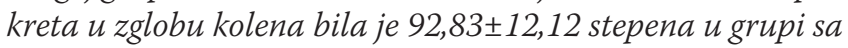
repozicijom kolena, dok u drugoj grupi je bila 91,05 $\pm 10,10$ pre operacije. Nakon hirurške intervencije, ovaj skor je u pr-

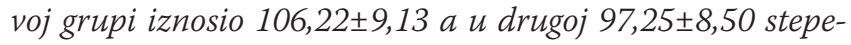
na. Od ukupnog broja pacijenata, kod 12 pacijenata je bio prisutan bol prednjeg kolena u grupi sa repozicijom, dok $u$ drugoj grupi je bilo 13 pacijenata pre operacije sa prisutnim bolom. Nakon operacije, 1 pacijent u prvog grupi $i 9$ pacijenata sa pristunim bolom je zabeleženo.

Odnos prisutnog prednjeg bola kolena je bio manji u grupi pacijenata sa repozicijom kolena u odnosu na drugu grupu, sa značajnom razlikom u obimu pokreta zgloba kolena. Preporučujemo repoziciju patele u zglobu kolena.

Ključne reči: patela, pokretljivost zgloba kolena, operacija 


\section{INTRODUCTION}

Knee arthroplasty is the last-stage treatment modality for gonarthrosis. New knee arthroplasty designs are obtaining better clinical results with a long survival rate period. In particular, patellar components had complications, which resulted in revisions in the early designs (1).

Anterior knee pain is an unwanted complaint that can be seen after knee arthroplasty. The rate of anterior knee pain is approximately $8 \%$ after primary knee arthroplasty (2). The exact aetiology of the anterior knee pain after primary knee arthroplasty is unknown. According to one opinion, high- compressive forces create pressure on the unresurfaced patellae, and this pressure may result in cartilage erosion on the patellar surface after knee joint replacement (3). Some study results offer patellar resurfacing to reduce anterior knee pain after knee arthroplasty $(4,5)$. Re-operation rates, because of anterior knee pain, are decreased by patellar resurfacing after total knee arthroplasty (6). However, patellar osteonecrosis, loosening of a patellar component, wear, extensor mechanism rupture and patellar maltracking are some of the complications that can be faced after patellar resurfacing (7).

Exact indications of patellar resurfacing include severe destruction of the patellofemoral joint, patellar maltracking, and inflammatory arthritis, such as rheumatoid arthritis and patellar and femoral component incongruency (8).

There are currently 3 approaches for patellar resurfacing. The first approach is always to resurface the patella; the second one is never to resurface the patella, and the third one is to resurface the patella, selectively, according to the quality of the articular cartilage and the congruence of the patellofemoral joint at the time of surgery (9).

We aimed to compare the clinical results, range of knee motions and anterior knee pain in patients on whom we performed knee arthroplasty with and without patellar resurfacing in this study.

\section{MATERIALS AND METHODS}

Approval for the study was granted by the University Ethics Committee with decision no 62 in 05.02.2018. Informed consent was obtained from all the patients. The inclusion criteria for this retrospective study were patients who had received posterior cruciate retaining knee arthroplasty and follow-up of more than 1 year. There were 52 patients, but 14 patients had a follow-up period of less than 1 year and were thus excluded from the study. A total of 38 patients in our clinic met these criteria. Demographic data were obtained from a total of 38 patients retrospectively. KSS scores, knee range of motion and anterior knee pain before and 12 months after surgery were detected from patient hospital files. Patients were divided into two groups: resurfaced patellas and nonresurfaced patellas. There were 18 patients in the resurfaced group and 20 patients in the nonresurfaced group.

\section{SURGICAL TECHNIQUE AND POST-OPERATIVE PHYSICAL THERAPY}

All knees were operated with midline incision and a medial parapatellar capsular incision to expose the knee joint. Dissection of the vastus medialis started from the quadriceps tendon with distal extension through the medial patellar retinaculum to the medial border of the patellar ligament. The synovium was incised in line with the capsular incision. The patella was everted or subluxated laterally. Cruciate retaining, fixed-bearing prostheses were implanted to all knees. Cement was used for the fixation of components. Patellar resurfacing was performed with the onlay technique; an equivalent thickness of bone was removed with the patellar component. In the nonresurfaced patellas, osteophytes were removed. An extramedullary alignment guide was used for the tibia, and an intramedullary alignment guide was used for the femur. The tibial cut was with an angle of $3^{\circ}-5^{\circ}$ for the tibial posterior slope. The distal femur was resected at $7^{\circ}$ valgus. The patella was resurfaced using a standard cemented polyethylene patellar button.

The decisions on performing either patellar resurfacing or patellar retention were based on the surgeon's subjective judgement.

Postoperatively, mobilisation was performed on the first day after surgery. Static quadriceps exercises, straight leg raising exercise and range of motion exercise were started from day 1 after surgery. Below-knee thromboembolic disease stockings were used for both lower extremities, and chemical prophylaxis for deep vein thrombosis was in the form of tablet acetylsalicylic acid $100 \mathrm{mg}$ once a day for 6 weeks. Perioperative intravenous cefazolin sodium was given to all patients for 24 hours.

The same physical therapy protocol applied to all patients after discharge from hospital.

Table 1: Demographic and clinical results of the groups.

\begin{tabular}{|c|c|c|c|c|c|c|c|c|}
\hline & $\begin{array}{l}\text { Number of } \\
\text { patients }\end{array}$ & $\begin{array}{l}\text { Follow } \\
\text { up period } \\
\text { (month) }\end{array}$ & $\begin{array}{l}\text { Mean Pre } \\
\text { operative } \\
\text { knee sociaty } \\
\text { score }\end{array}$ & $\begin{array}{l}\text { Mean Post } \\
\text { operative } \\
\text { knee sociaty } \\
\text { score }\end{array}$ & $\begin{array}{l}\text { Mean pre } \\
\text { operative } \\
\text { knee range } \\
\text { of motion } \\
\text { (Degree) }\end{array}$ & $\begin{array}{l}\text { Mean post } \\
\text { operative } \\
\text { knee range } \\
\text { of motion } \\
\text { (degree) }\end{array}$ & $\begin{array}{l}\text { Number of } \\
\text { patients with } \\
\text { anterior knee } \\
\text { pain pre } \\
\text { operatively } \\
\end{array}$ & $\begin{array}{l}\text { Number of } \\
\text { patients with } \\
\text { anterior knee } \\
\text { pain pre } \\
\text { operatively }\end{array}$ \\
\hline Total & 38 & $20,42 \pm 4,94$ & $39,57 \pm 9,89$ & $80,23 \pm 5,76$ & $91,89 \pm 10,99$ & $101,50 \pm 9,8$ & 25 & 10 \\
\hline $\begin{array}{l}\text { Resurfaced } \\
\text { group }\end{array}$ & 18 & $18,27 \pm 2,98$ & $40,72 \pm 13,09$ & $80,38 \pm 7,78$ & $92,83 \pm 12,12$ & $106,22 \pm 9,13$ & 12 & 1 \\
\hline $\begin{array}{l}\text { Non resurfaced } \\
\text { group }\end{array}$ & 20 & $22,35 \pm 5,59$ & $38,55 \pm 5,88$ & $80,10 \pm 3,22$ & $91,05 \pm 10,10$ & $97,25 \pm 8,50$ & 13 & 9 \\
\hline
\end{tabular}




\section{STATISTICAL ANALYSIS}

Parametric tests were used because the data had normal distribution. Student's $t$ test for continuous variables, chi-square test for categorical data and paired $t$ test for comparison of pre- and post-operative values were used in the comparison of the two groups. At the $95 \%$ confidence interval, $\mathrm{p}<0.05$ was considered significant.

\section{RESULTS}

Mean age of the patients was $70.55 \pm 6,03$ years. Mean follow-up period was $20.42 \pm 4.94$ months. Mean Knee Society score was $39.57 \pm 9.89$, and mean knee range of motion was $91.89 \pm 10.99$ before surgery. In the last control, mean Knee Society score was $80.23 \pm 5.76$, and mean knee range of motion was $101.50 \pm 9.8$ degrees. Mean follow-up period was $18.27 \pm 2.98$ months in the patellar resurfaced group and $22.35 \pm 5.59$ months in the nonresurfaced group. Mean Knee Society score was $40.72 \pm 13.09$ in the resurfaced group and $38.55 \pm 5.88$ in the nonresurfaced group before surgery. Mean Knee Society score was $80.38 \pm 7.78$ in the resurfaced group and $80.10 \pm 3.22$ in the nonresurfaced group in the last control. Mean knee range of motion was $92.83 \pm 12.12$ degrees in the resurfaced group and $91.05 \pm 10.10$ degrees in the nonresurfaced group before surgery. Mean range of motion was 106.22 \pm 9.13 degrees in the resurfaced group and $97.25 \pm 8.50$ degrees in the nonresurfaced group after surgery. A total of 25 patients had anterior knee pain before the surgery. Twelve patients with anterior pain before surgery were in the resurfaced group, and 13 patients had anterior knee pain in the nonresurfaced group. After surgery, there was 1 (5,5\%) patient with anterior knee pain in the resurfaced group, and there were 9 (45\%) patients with anterior knee pain in the nonresurfaced group in the last control. There was no significant difference between Knee Society scores of both groups in the last control after surgery $(p>0,05)$. A significant difference was detected in Knee Society scores before and after surgery in both groups $(\mathrm{p}<0,05)$. There was a significant difference between groups in range of knee motion in the last control after surgery $(p<0,05)$. The resurfaced group had higher angular values than did the nonresurfaced group. We detected a significant difference in anterior knee pain after surgery in the last control between groups $(\mathrm{p}<0,05)$. The resurfaced group had less anterior knee pain than did the nonresurfaced group. No reoperation was performed and no reinfection was detected.

\section{DISCUSSION}

Anterior knee pain is one of the important conditions where the exact aetiology is not understood. Excessive patello-femoral loads and abnormal patellar tracking can be the reason for anterior knee pain (10). According to the results of the study that was done by Erduran et al., patellar tilt had an increase in gonarthrotic patients compared to the control group. The congruence angle was lower in knees with gonarthrosis at $0^{\circ}$ and $10^{\circ}$ of knee flexion but higher at $20^{\circ}, 30^{\circ}, 40^{\circ}$ and $60^{\circ}$ than in knees in the control group. They found an increase in congruence angle with the contraction of the quadriceps in the control group, but no significant changes were observed in patients. As a result of their study, the differences in dynamics of the patellofemoral joint in patients with gonarthrosis can be the reason for patellofemoral complaints after knee arthroplasty (11). Another study about the effect of lower extremity torsional deformities on anterior knee pain showed that lower extremity torsional deformities are not the primary aetiologic reason for patellofemoral instability and anterior knee pain (12). Heergaard et al. showed that after total knee arthroplast, patellar tracking changes, and this change increases patellofemoral contact pressures. These increased pressures can be the reason for anterior knee pain after knee arthroplasty (13). According to our results, there was 1 patient with anterior knee pain in the patellar resurfaced group, but there were 9 patients in the nonresurfaced group. Our clinical results are consistent with the results of these biomechanical studies.

In a study with 116 patients who had been performed cruciate-retaining knee arthroplasty, 68 knees had patellar resurfacing and 48 had patellar retention, and the mean follow-up period was 14,8 years. No significant difference was detected in either clinical or radiological results between the two groups (14). Another study with medium followup period found patellar resurfacing had no advantage on knee function and patient satisfaction (15). No significant difference in functional outcome was detected between patellar resurfacing and retention in a randomised controlled trial including 1715 patients (16). There was no significant difference in Knee Society scores between resurfaced and nonresurfaced groups, but there was a significant difference in knee range of motion. Higher values of range of motion angles were detected in the resurfaced group.

Results of the meta-analysis done by Tang et al., which compared patellar resurfacing and retention in total knee arthroplasty with a follow-up period of 1 to 2 years, showed patellar resurfacing increases the Knee Society Clinical Score and reduces the reoperation rates (17). There was no significant difference in Knee Society scores between groups, and there was no reoperation in either group in our study. Proponents of the patellar resurfacing emphasise the low reoperation rates and low incidence of anterior knee pain after knee arthroplasty with patellar resurfacing $(18,19)$.

Theratio of anterior knee pain after patellar resurfacing was $1 \%-5 \%$, but in the retention group, the anterior knee pain ratiowas $10 \%-14 \%(20,21)$. Our results showed $45 \%$ anterior kneepain in the nonresurfaced group, and this result is higherthan in the literature. The anterior knee pain ratio in the re-surfaced group is compatible with the literature.

In the results of the study done by Pilling et al., there was no significant difference in patient satisfaction, infection rate, anterior knee pain and knee rating systems between patellar resurfacing and retention, although there 
was a difference in Knee Society Score. However, the reoperation rate is significantly lower in the patellar resurfacing group (22). There was no reoperation in our series, but our follow-up period was short. The short follow-up period is one the most important restrictions of our study.

Barrack et al. showed as a result of their randomised controlled study (23) that, postoperatively, the ratio of anterior knee pain was $28 \%$ with resurfaced patellae, despite the fact that none of the patients had any anterior knee pain before the knee arthroplasty procedure. Our results are not consistent with the results of this study

\section{CONCLUSIONS}

Smaller anterior knee pain ratio in the resurfaced group than in the nonresurfaced group and a significant difference in range of knee motion are the results of our study. We offered to resurface the patella.

\section{REFERENCES}

1. Campbell DG, Duncan WW, Ashworth M, Mintz A, Stirling J, Wakefield L, Stevenson TM. Patellar resurfacing in total knee arthroplasty: a ten-year randomized prospective trial. J Bone Joint Surg Br. 2006;88:734-9.

2. Petersen W, Rembitzki IV, Brüggemann GP, Ellermann A, Best R, Koppenburg AG, Liebau C. Anterior knee pain after total knee arthroplasty: a narrative review. Int Orthop 2014; 38: 319-28

3. Forster H, Fisher J:The influence of continuous sliding and subsequent surface wear on the friction of articular cartilage. Proc Inst Mech Eng H 1999;213:329-45

4. Clements W J, Miller L, Whitehouse S L, Graves S E, Ryan P, Crawford R W. Early outcomes of patella resurfacing in total knee arthroplasty. Acta Orthop 2010; 81: 108-13.

5. Helmy N, Anglin C, Greidanus N V, Masri B A. To resurface or not to resurface the patella in total knee arthroplasty. Clin Orthop Relat Res 2008; 466 : 2775-83.

6. Pakos EE, Nizani EE, Trikalinos TA.. Patellar resurfacing in total knee arthroplasty. A meta analysis. J Bone Joint Surg Am. 2005;87:1438-45.

7. Parvizi J, Rapuri VR, Saleh KJ, Kuskowski MA, Sharkey PF, Mont MA. Failure to resurface the patella during total knee arthroplasty may result in more knee pain and secondary surgery. Clin Orthop Relat Res. 2005;438:191-6.

8. Matthew P. Abdel\&Sébastien Parratte\&Nicolaas C. Budhiparama. The patella in total knee arthroplasty: to resurface or not is the question. Curr Rev Musculoskelet Med 2014; 7:117-24

9. Atik Ş. Is routine patellar resurfacing in total knee arthroplasty necessary? Eklem Hastalık Cerrahisi 2010;21:61

10. Konno T, Onodera T, Nishio Y, Kasahara Y, Iwasaki N, Majima T. Correlation between knee kinematics and patellofemoral contact pressure in total knee arthroplasty. J Arthroplasty2014; 29:2305-8
11. Erduran M, Akseki D, Karaoğlan O, Pınar H. Patellofemoral joint dynamics in patients with gonarthrosis Eklem Hastalık Cerrahisi 2009;20:18-24

12. Yercan H.S, Taşkıran E. The Relationship Between Lower Extremity Torsional Deformities And Patellofemoral Disorders. Eklem Hastalıkları Cerrahisi 2004 ; 15: 71-5

13. Heegaard JH, Leyvraz PF, Hovey CB. A computer model to simulate patellar biomechanics following total knee replacement: the effects of femoral component alignment. Clin Biomech (Bristol, Avon). 2001;16:415-23.

14. Chun KC, Lee SH, Baik JS, Kook SH, Han JK, Chun CH. Clinical and radiological results ofcruciate-retaining total knee arthroplasty with the NexGen ${ }^{\circ} \mathrm{CR}$ system: comparison of patellar resurfacing versus retention with more than 14 years of follow-up. J Orthop Surg Res. $2017 ; 12: 144$.

15. Ali A, Lindstrand A, Nilsdotter A, Sundberg M. Similar patient-reported outcomes and performance after total knee arthroplastywith or without patellar resurfacing. Acta Orthop. 2016 ;87:274-9.

16. Breeman S, Campbell M, Dakin H, Fiddian N, Fitzpatrick R, Grant A, Gray A, Johnston L, Maclennan G, Morris R, Murray D, KAT Trial Group:Patellar resurfacing in total knee replacement: five-year clinical and economic results of a large randomized controlled trial.J Bone Joint Surg Am2011, 93:1473-81.

17. Tang XB, Wang J, Dong PL, Zhou R. A Meta-Analysis of Patellar Replacement in Total Knee Arthroplasty for Patients With Knee Osteoarthritis. J Arthroplasty. 2018;33:960-7

18. Waters TS, Bentley G:Patellar resurfacing in total knee arthroplasty - A prospective, randomized study.J Bone Joint Surg Am2003,85A:212-7.

19. Tabutin J, Banon F, Catonne Y, Grobost J, Tessier $\mathrm{JL}$, Tillie B:Should we resurface the patella in total knee replacement? Experience with the Nex Gen prothesis.Knee Surg Sports Traumatol Arthrosc2005,13:534-8

20. Li B, Bai L, Fu Y, Wang G, He M, Wang J. Comparison of clinical outcomes between patellar resurfacing and nonresurfacing in total knee arthroplasty: retrospective study of 130 cases. J Int Med Res 2012; 40: 1794-1803

21. Boyd AD, Ewald FC, Thomas WH, Poss R, Sledge CB. Long-term complications after total knee arthroplasty with or without resurfacing of the patella. J Bone Joint Surg Am1993; 75: 674-81

22. Pilling RW, Moulder E, Allgar V, Messner J, Sun Z, Mohsen A Patellar resurfacing in primary total knee replacement: a meta-analysis. J Bone Joint Surg Am 2012;94:2270-8

23. Barrack RL, Bertot AJ, Wolfe MW, Waldman DA, Milicic M, Myers L. Patellar resurfacing in total knee arthroplasty. A prospective, randomized, double-blind study with five to seven years of follow-up. J Bone Joint Surg Am. 2001;83:1376-81. 